\title{
Reckoning Participatory Forest Management in Bangladesh: Study from Its Implementation Perspective
}

\author{
Sourovi Zaman (Corresponding author) \\ AFC, Forest Measurement and Planning Laboratory, Forest Science Department \\ Agriculture Faculty, Shinshu University, 8304, Minami-minowa, Kami-ina, Nagano-399-4598, Japan \\ Tel: 81-265-771-642_E-mail: sourovi_zamanbd@yahoo.com \\ Salah Uddin Siddiquee \\ AFC, Insect Ecology Laboratory, Entomology Department, Agriculture 11 Faculty \\ Shinshu University, 8304, Minami-minowa, Kami-ina, Nagano-399-4598, Japan \\ Tel: 81-265-763-389_E-mail: babu052002@yahoo.com \\ Mohammad Abdullah Al Faruq \\ AFC, Forest Measurement and Planning Laboratory, Forest Science Department \\ Agriculture Faculty, Shinshu University, 8304, Minami-minowa, Kami-ina, Nagano-399-4598, Japan \\ Tel: 81-265-771-642Ｅ-mail: faruq1010@yahoo.com
}

Mahfuzur Rahamn Pramanik

Forest Management/Silvicultural Systems Laboratory, Forest Science Department, Agriculture Faculty Shinshu University, 8304, Minami-minowa, Kami-ina, Nagano-399-4598, Japan

Tel: 81-265-77-1519 E-mail: mahfuzur.rp@gmail.com

Masato Katoh

AFC, Forest Measurement and Planning Laboratory, Forest Science Department, Agriculture Faculty

Shinshu University, 8304, Minami-minowa, Kami-ina, Nagano-399-4598, 5 Japan

Tel: 81-265-771-642Ｅ-mail: mkatoh@shinshu-u.ac.jp

Received: December 22, 2010 Accepted: January 7, 2011 doi:10.5539/jas.v3n3p233

\begin{abstract}
s
Once upon a time Bangladesh was famous for its tropical evergreen and mangrove forest. But over the years due to over exploitation of forests and its non-participatory management, more than $50 \%$ of the forest resources have been depleted. Realizing the grim effect of destruction of forests and to repair the lapidated environmental condition, both the government and non-government organization have taken up afforestation program. The NGOs have added a new dimension in the forest management, which has ensured participation of the community people and protection of the vegetation. Although, the government has also adopted participatory forest management but due to bureaucratic attitude easy access of the poor habitants are restricted in many cases. To overcome these situations, the existing government forestry policy, needs radical modification. There should be room to accommodate the NGOs, grass root organizations and general people in policy formulation, execution and evaluation of the program.
\end{abstract}

Keywords: Participatory forest, Afforestation, Forest policy, Bangladesh

\section{Introduction}

Social Forestry programs have been initiated with a view to meet the forest product requirements of local 
population and to reverse the process of ecological and climatic degradation through proper soil and water conservation and to improve the socio economic condition of the rural people. Since the early 1980s there has been an unprecedented enthusiasm for social forestry (SF) in Bangladesh (BBS 2002). The government has attached the highest priority to SF, and it has become the dominant strategy in the country's forestry sector. The goals of SF are somewhat all-encompassing and, perhaps, over-ambitious. These goals most commonly include empowering 'the weaker sections' of local communities through active participation in the management and use of forests; promoting a cooperative structure to articulate the interests and voices of local people; meeting local forestry needs; and promoting self-sufficiency and social equity among local communities (Rahman, 1992). Bangladesh lies in the North-Eastern part of South Asia between 20o34' and 26o38' North in latitude and between $88 \mathrm{ol}$ ' and $92041^{\prime}$ East in longitude. The total area or the country is 144,000 sq. Km with a population of about 120 million, density of population is 800 people per square kilometer. The most densely populated country in the world, Bangladesh is mainly a floodplain delta (Chowdhury QI 1999). Natural forest represents only 6 percent of the total land area of the country and is managed and controlled by the government. Village forest which contains annual and perennial trees and still provides a major source of food and income for majority of people is managed by private individuals. A rapidly increasing population is placing growing demand on natural resources; especially forest sector is under pressure to become more productive and efficient to keep pace with increasing demand. At present forest in Bangladesh is in unfavorable situation in terms of meeting increasing demand and also not adequate for maintaining ecological balance (Roy, 2003). This is primarily due to heavy population pressure and limited resource base, secondly, lack of integrated planning for development of multiple resource bases with active participation of people resulting in high degree of environmental degradation, as illustrated mostly by deforestation and destruction of Natural resources. In the phase of rapid depletion of forest aggravated by increasing demand for forest resources, and considering the prevailing socio-economic condition of the country, Government has put emphasis on participatory approach in development of forest resources of the country (Alauddin 1998).

\section{Objectives and research methodology}

Sustainable forest management and development are the major targets of the global community. As a member of the global community and signatory to various international forums and protocols, a nation assumes the responsibility of incorporating, into national forestry directives, available international guidelines on sustainable forestry such as forest certification, International Tropical Timber Organization (ITTO) guidelines, Kyoto protocol and other appropriate UN environmental and related protocols. The current study included a critical review and analysis of participatory forest planning in Bangladesh with regard to international sustainable forestry development. The main focus of this research was sustainable forest management with participatory forestry and its sequential development. As such, some relevant sustainable development processes have been reviewed and discussed from a perspective of the Bangladesh forestry situation. An analytical review of historical social forestry in Bangladesh, strategy and development goals was conducted. The Forest social forestry and forest management were reviewed and analyzed, as were Bangladesh forestry documents and relevant literature. A brief review of relevant regional and sectoral policies was conducted. Additionally a semi-structured questionnaire survey was completed by interviewing experts and professionals to analyze the strengths and weaknesses of the present policy. On the basis of the results of this exercise, a set of recommendations was constructed to act as potential guidelines for future policy formulation.

\subsection{Present forest situation in Bangladesh}

Bangladesh was very rich and famous for forest resource over the period but at present the actual forest coverage is only 10 percent of the total area and the situation is worsening despite of an attempt to preserve it. At approximately 0.02 ha per person of forest, Bangladesh currently has one of the lowest per capita forest ratio in the world. In Bangladesh, government-owned forest area covers 2.19 million ha, with the remaining 0.27 million ha being privately controlled homestead forests (GOB 2005). Of the government owned forest land, 1.49 million ha are national forests under the control of the Department of Forest, with the rest being under control of local governments. Of the state owned forests, over $90 \%$ is concentrated in 12 districts in the Eastern and South-Western region of the country. However, due to over exploitation these forests have become seriously degraded. The natural forests of the country are classified into three categories: 1) Tropical evergreen/ semi-evergreen forest in the eastern districts of Sylhet, Chittagong, Chittagong Hill Tracts, and Cox's Bazaar: 2) Moist/dry deciduous forest also known as Sal forests in the central and the northwest region and 3) Tidal mangrove forest along the coast, known as the sundarban, the largest mangrove ecosystem in the world (GOB 1995). These forests are official reserves and placed under the jurisdiction of the Forest Department. Unfortunately, recent inventories indicate a continuing depletion of all major forests. 


\section{Forest management in Bangladesh}

In Bangladesh management of government forest is the responsibility of the Forest Department under the Ministry of Environment and Forest. In this process the department is managing, protecting, developing the forest resources, forest land and also collecting the revenues. People have never been consulted nor involved in forestry activities. From the management point of view, forest of Bangladesh is divided into (a) Hill Forests; (b) Plain land Sal Forests, (c) Mangrove Forests (GOB 1995).

Hill Forests: The tropical evergreen/semi evergreen forest cover as approximately 1.32 million ha of which 0.67 million ha is controlled by the forest department and rest is under the control of hill district council (BBS 2004). Clear felling followed by replanting with suitable species (both long and short rotation) is the method of management in hill forest. The country forest has greatly affected and rate of denudation is considerably high because of increased demand for timber and fuel wood and prevailing socio-economic condition (SFR 2004). The forest department is mainly confined in rising of single species plantation. Inventory shows that most of these plantations would not give the desirable output. This program suffers from technical, social and administrative soundness. Another problem is most of the high forest are subjected to shifting cultivation by the hill tribes. The tribes are entitled to shifting cultivation in forest land under administrative control of district administration which has resulted in the total destruction of these tropical evergreen forests (FD 2004).

Mangrove Forests: Known as Sundarbans, the largest mangrove ecosystem in the world. Sundarban forests are being managed by selection felling method followed by natural regeneration. Beside Sundarbans, plantations are being raised with mangrove species in the newly accreted char land all along the Coast of the Bay of Bengal. Sundarban forest is an official reserve forest; unfortunately recent inventory shows a continuous depletion due to over-cutting, illegal felling. It is estimated that in less then 25 years, the volume of commercial species Sundari, Gewa, has declined by 40 to $50 \%$ respectively (FAO 2007).

Plain land Sal Forests/ Tropical moist deciduous forest: Silvicultural system applied for Sal forest was coppice with standard system. In this system matured trees were felled and the areas were protected for coppice regeneration (Alauddin 1998). The typical nature of Sal forest is that this forest is scattered. In the forest areas there are agricultural lands owned by the adjacent people. Frequently these land owners are extending their lands and encroaching to forest and in the process they are destroying the forest and subsequently converting the area to agricultural land. In this process forest lands are being marginalized day by day. FAO estimated that only $36 \%$ of the Sal forest cover remained in 1985; more recent estimates that only $10 \%$ of the forest covers remain due to over exploitation and illicit felling through there is an official base on logging since 1972 (FAO 2007). Most of the Sal forests are now substantially degraded and poorly stocked. The situation calls by for involvement of community people in the forest management.

Over-cutting by timber merchants, increased consumption linked to population growth, shifting cultivation, encroachment, illegal felling and land clearing for agriculture, lack of participatory management have been the principal causes of deforestation and shrinking of forest land in the country (Khan et al 2004). Since 1960 two major approaches regarding the role of forestry in development have been reflected in the forestry sector of Bangladesh. In the 1960's, Bangladesh as a part of Pakistan and then as an independent nation has followed Industrialization Approach' consonants with the international conventional wisdom at that time (BBS 1999). As a result, Department of Forest raised large-scale Industrial plantation which were seen as conversion of low-yielding natural forest into artificial plantation of species (mostly teak) of great economic importance. This conversion of semi-evergreen and evergreen forest into deciduous teak plantation was largely concentrated in hill forest areas. During the plantation raising local people were not consulted and often they did not drive any benefits from these plantations. The lack of support by the local people/ communities in combination with lack of silvicultural knowledge and lack of proper maintenance contributed to raise low quality plantations and these plantations were also lost due to illegal felling. In the name of plantation the genetic resource of the evergreen/ semi-evergreen forest was lost. Forest Department was considered as revenue earning department (Roy 2003). The main activities of Forest Department were concentrated in extraction of trees from the forest and replanting of those felled areas where applicable, Forest Department has not considered the people and their participation in managing forest of the country. In the 1980s following a change in thinking about the role of forestry in development, and people's participation in forestry activity was encouraged. People participation with the forestry sector realized the need of people oriented forestry program to replenish the degraded forest resources of the country (Alim 1988). Accordingly, in 1994 Government formulated a forest policy replacing earlier one enunciated in 1979 with a due emphasis to the need for people's participation in forest management (Choudhury 2003). 


\section{Participatory forest management approach in Bangladesh}

\subsection{Past activities}

Forest extension activities were formally launched in the country in the year of 1964 with the establishment of two forest extension divisions at Dhaka and Rajshahi and later two divisions at Comilla and Jessore (Khan 1998). It was really a very small program and the activities were confined only to establish nursery in the districts headquarter and raised seedling and sell the same to individuals and organizations. The location of this program was so urbanized and limited that it only partially served the needs of the effluent town dwellers only.

\subsection{Betagi- pomora comunity forestry project}

The first community forestry program in the country, started at Betagi and Pomora mouza (village) under the district of Chittagong in the year of 1979 (GEMS 1984; Zaman 1984). Initially the project covered 160 ha of Government denuded hilly land at Betagi and with 83 landless participants from adjacent community and subsequently extend over another 205 ha of Government owned denuded hilly land at Pomora with another batch of 243 landless (families) participants (BBS 1993). Under this program each landless participant was provided with 1.62 ha of land for growing tree and horticultural crops with technical and financial assistance from the Forest Department. This community program has given the landless an identity and a sense of direction in life. But this model has not been replicated in the other areas due to lack of initiative of the Forest Department as well as the Government (MOEF/IUCN 1990).

\subsection{Development of community forests project}

The activities of the first phase of this project began in 1981 and were completed in 1987 in seven greater districts of the North-Western zone of the country. The main apparatus of the project were; strip plantations along roads and highways, railways, canal sides, district and Union Parishad roads, totalling about 4,000 km; Fuelwood plantation on 4800 ha of depleted Government land on participatory concept; Agroforestry demonstration farms over 120 ha also with participatory concept; Replenishment of depleted homestead wood lots in 4,650 villages; Training of Forest Department Personnel and Village leaders (Rashid 1994).

\subsection{Thana afforestation and nursery development project}

This project is a follow-up of Development of Community Forestry Project and Forest Extension Project and has been designed primarily to: increase the production of biomass fuels and enhance the institutional capability of FD and local administration in implementing a self-sustaining nationwide social forestry program (BBS 2002). In order to increase the production of biomass fuel and to arrest the depletion of tree resources, the project envisaged to develop tree resources base through planting of depleted sal forest as well as brining all suitable and available land in the rural areas under tree cover with active participation of the rural poor of the locality. Originally the project was to be implemented by the Forest Department and former Thana Parishad (sub-district) during the period of 1987 to 1994 . But in 1992 Government decided that the all project activities were to be implemented by Forest department alone; whereas the Government has found that this was quite impossible to protect the strip plantation and also impossible to trained 76,000 people by the Forest Department alone (Rahim et al 1998). The Government invited different NGOs to participate in this program for successful implementation and they came forward to help the Government for successful completion of the project; NGOs employed their group members to protect the strip plantation and came forward to train people at different levels with the help of its member organizations. The above plantation activities were carried out with the local people with the help of the NGOs by executing benefit sharing agreement.

\subsection{Rehabilitation of Jhumia families (shifting cultivator families)}

Another project was undertaken by the Forest Department in the Hill tract areas to establish plantation through rehabilitation of Jhumia families in 1980 to rehabilitate tribal families in the Unclassed State Forest (USF) lands along with rehabilitation of denuded USP land; to introduce a sustainable agroforestry production system and to improve the socio-economic condition of tribal people and motivate tribal people in development of forestry (BBS 1993).

Under this program each family was allocated 2.02 ha of USF land for growing agricultural crops (over $1.20 \mathrm{ha}$ ), raising plantation $(0.80 \mathrm{ha})$ and for house construction $(0.20 \mathrm{ha})$. The rehabilitated families were given land use rights and were allowed to enjoy $100 \%$ benefits accrued to those lands. The participants were given input support for growing agriculture, horticulture and forestry crops and cash support for house construction (Alim 1988). This program continues for quite a long period of time but could not sustain mainly because of nomadic character of the tribal groups. Another reason of failure was that the families were rehabilitated in clustered villages without considering their cultural and religious values. 


\subsection{Coastal greenbelt project}

Another project financed by Asian Development Bank is under implementation in the Coastal region of Bangladesh. The main objective of the project is to create a vegetative belt all along the coast to save the lives and properties of the people living in the coastal areas from devastated cyclone and tidal surges which occur very frequently in those areas. All of the activities of this project are also being carried out following participatory approach (Task Force 1987). In this project also the participants have been selected among the poor people living in the adjacent areas by involving NGO and a pre-designed benefit sharing agreements also being executed with the participants to protect their rights over plantations and to ensure benefit expected to be received out of the plantation (FSP 2003).

\subsection{Agroforestry project}

Agroforestry Research and Demonstration was implemented by the FD in the Sal forest areas. The project had been developed precisely to design/develop agroforestry modules which is environmentally feasible, socio-economically acceptable enhance tree and crop production at the same time to uplift the socio-economic condition of the participants (Rahman 1992). The project aimed at using 120 ha of encroached Sal Forest land of Dhaka, Mymenshing and Tangail Forest Division to develop suitable participatory plantation models.

\subsection{Food assisted social forestry program}

The World Food Program assisted the Government to develop Social Forestry as a national program and the Government incorporated WFP assisted social forestry program in its annual development plan from 1998 (FAO 2001). Poverty alleviation, economic rehabilitation of rural poor especially the destitute women of the society by engaging them in forestry activities, social uplift of rural poor and environmental improvement are the main objectives of this project (FD 2002). Historically this program was conceived in the country since 1989 on pilot basis allocating in kind resources (Wheat) to a limited number of NGOs for raising strip plantation along roads, embankments, Highways etc. in rural areas following the participatory mechanism. At present probably this is the largest Participatory Forestry Program in Bangladesh. From 1990, 100 NGOs are involved in this program and at present about 60 NGOs are continuing with the program. Commencing from 1990 up to 1998 about 31 million trees were planted involving 0.062 million people directly and 0.62 million people indirectly (SFR 2002). The program has created employment to the tune of 68 million man days. This program is being implemented by the NGOs through contractual benefit sharing among participating poor men \& women $60 \%$, NGOs $10 \%$, the rest land owners.

\section{NGO contribution in the participatory forest management}

In Bangladesh the history of NGO involvement in the field of development is not very old. After liberation, NGO started their activities through relief and rehabilitation of the war victims. During mid-seventies, NGO switched over to the socio-economic development of the rural poor, and at present there are thousands of NGOs most of whose mandate is to organize rural poor and provide awareness, education, skill training and various support services including credit to enhance participation of landless poor in the development process towards self reliance. On the basis of the networking throughout the country the NGO can be classified into two levels, Local and National. At present more than $100 \mathrm{NGOs}$ both local and National are implementing social forestry program in Bangladesh (BBS 2007). It is not possible to enlist activities of all the NGOs involved in the Social forestry program in the country. The participatory forestry activities of some of the NGOs are highlighted here who are playing pioneer role in this field. Different NGO works with a few projects/ programs in broad sense among which Social Forestry falls within rural development program. The Social/ Participatory forestry has three components; Nursery establishment, Plantation and Establishment of agroforestry. They claim that they have assisted their women members in raising more than 225 homestead nurseries and 100 large nurseries with a combined production capacity of a million seedlings of fruits and forest seedlings (FSP 2007). They have established 200 mulberry nurseries with the production capacity of 2 million seedlings. NGO`s has introduced its group members in social forestry activities and provided them with credit and technical support, which contributed significantly to their self-sufficiency (Mia 2009). The main components of social forestry program of the NGO's are; i) Homestead plantation; ii) Strip and block plantation; iii) Natural Forest protection, and iv) Nursery establishment. Different NGO`s has planted 71 million seedlings which covered along 8,887 km strips, 37,662 areas of block plantation which included natural Sal forest protection throughout the country. One of the most significant contributor of NGO's to the development arena is the introduction of the concept of participatory forest management for natural forest protection. Different NGO's has successfully involved the forest dwellers in the Sal forest areas of Dinajpur, Thakurgaon, Tangail and Gazipur for the protection of coppice Sal forest by involving group members. It has already been proved that when poor people surviving on the forest resources are organized, trained and granted usufruct rights, they present on enormous human potential needed for afforestation and forest protection (FAO 2007). 
Several NGOs are operating in Northern Bangladesh for more than two decades. Its entry point in forestry was through road side plantation in 1977. Initially, seedlings were protected with bamboo cages. Situation has been changed a lot nowadays and protection of seedlings with bamboo cage has become a part of history (BBS 2007). Besides strip plantation, they also extend their tree plantation program in homestead, institutional grounds as well as rising of local nurseries. With the assistance of Forest Department they have planted about 10.66 million trees under their participatory afforestation program.

\section{Problems and Present scenario of participatory forest management}

Considering the demand and supply situation for forest products to meet the economic and environmental needs, no one can deny the need of people's participation in forestry. Probably there is no second answer except participatory forestry in developing, managing, and protecting the country's forest land and the forest resource. But there are numbers of issues remain unresolved. As a technical department, Forest Department is playing pioneer role in implementing and popularizing Participatory Forestry in the country (GOB 2005). Up to this time Forest Department is managed by the professional foresters who have educational background only in managing traditional forests and who do not consider people as development partners. Participatory Forestry needs mental development managers towards the people (Roy 2003). Realization has started among the planners, policy makers, administrators and senior managers to involve people in forestry development activities. But up to this time Government has failed to adopt real Participatory Forestry program to address the basic need of the peoples. Mobilization of the people in participatory forestry program is another bottleneck of the Forest Department who has not had the machinery to reach the community people. NGOs who work at the grassroots level have developed their own expert to mobilize people and ensure their participation in any development programs as partner. So NGO should be involved in the implementation of the participatory forestry program where Forest Department should confine their activities only in technical aspect. In the context of Bangladesh, the scarcity of land is a most vital problem. On the other hand, Forest Department controlling over $16 \%$ of the total land area of the country is still hesitant to allow Participatory Forestry in reserved forest areas. According to FD, it should be confined only in public and private lands beyond reserved forest areas through these are devoid of trees. The Participatory Forestry is being practiced in marginal lands which are under administration control of other Government departments (GOB 2005). Recently, due to pressure from planners and donor communities, Forest Department has allowed to practice participatory forestry in Sal Forest areas (FAO 2007). Tenure of the contract was found as a bottleneck for implementing Participatory Forestry. Forest Department allowed rights of participants over these lands for a period of seven years, but there was a strong desire, that this tenure should more and at least for rotation period, so that participants can manage and protect trees till harvesting. A negative attitude was also observed among the Foresters to involve women in forestry activities. They viewed that activities of women should be confined in the areas where there is a locality apprehending the social problems. But in participatory forestry both men and women should be treated equally.

\section{Recommendations}

The latest forest policy of 1994 needs a fundamental change to make participatory forestry approach as a core concept for social fencing against forest destruction and for poverty alleviation through income generation. An independent Forest Policy needs to be formulated to promote Participatory Forestry in the country. For implementing Participatory Forestry program, Land as an input is to be ensured with authority. Preset land lease system is neither responsive nor effective for practicing Participatory Forestry in the country. Provision should be made for giving subsistence to the participants so that they can survive and keep confined their activities in the program. A National forum where there will be representation all from Government politicians, NGOs and private sector should be developed where they will act as a coordination body to coordinate among all the participants like land owning agency, NGO, Forest Department and the participants. NGO should act as a catalyst and they should not be treated as a competitor of Forest Department. Reforestration and afforestation programs with community participation in a profit sharing basis and improvement in technology and management of plantation are required. Forestry professionals should be trained in environmentally sound forestry.

\section{References}

Alauddin, S. M. (1998). An Overview of Forest Management in Bangladesh. In: Proceedings of the workshop of IUFRO projects 5.17, India, 21-24

Alim, A. (1988). Forestry with the People and For the People. Institute of Forestry, University of Chittagong, Chittagong.

Bangladesh Bureau of Statics (BBS). (1993). Statistical Yearbook of Bangladesh. Bangladesh Bureau of Statistics, Dhaka 1994.

Bangladesh Bureau of Statics (BBS). (1999). Statistical Year Book of Bangladesh, Ministry of Planning, 
Government of the Peoples Republic of Bangladesh, Dhaka.

Bangladesh Bureau of Statics (BBS). (2002). Statistical Year Book of Bangladesh, Ministry of Planning, Government of the Peoples Republic of Bangladesh, Dhaka.

Bangladesh Bureau of Statics (BBS). (2004). Statistical Year Book of Bangladesh, Ministry of Planning, Government of the Peoples Republic of Bangladesh, Dhaka.

Bangladesh Bureau of Statics (BBS). (2007). Statistical Year Book of Bangladesh, Ministry of Planning, Government of the Peoples Republic of Bangladesh, Dhaka.

Choudhury, J. K. (2003). National forest policy review: Bangladesh. In: Enters T, Qiang M, Leslie RN (eds) An overview of forest policies in Asia. EC-FAO partnership program (2000-2002). FAO, Rome. 5-46

Chowdhury, Q. I. (1999). Bangladesh: country overview. In: Chowdhury QI (ed) Bangladesh state of environment report 1999. Forum of Environmental Journalists of Bangladesh, Dhaka, 1-14.

Food and Agriculture Organization. (FAO). (2001). Global forest resources assessment 2000, Rome.

Food and Agriculture Organization. (FAO). (2007). National Forest and Tree Resources Assessment 2005-2007. Bangladesh.

Forest Department (FD). (2002). Participatory Management Plans, Mymemsingh Forest Division (volume:1), Forestry Sector Project, Forest Department, Banbhaban, Mahakhali, Dhaka.

Forest Department (FD). (2004). Participatory Management Plans, Mymemsingh Forest Division (volume:1), Forest Department , Banbhaban, Mahakhali, Dhaka.

Forestry Sector Project (FSP). (2003). Participatory Forestry Newsletter, Bulletin 1, Forest Department, Dhaka. Forestry Sector Project (FSP). (2007). Participatory Forestry Newsletter, Bulletin 3 , Forest Department, Dhaka. GEMS: Forest Statistics for Bangladesh. (1984). Global Environment Monitoring System. Food and Agriculture Organization, Rome.

GOB. (1995). Development perspectives of the forestry sector master plan. Ministry of Environment and Forestry. Government of the Peoples' Republic of Bangladesh, Dhaka

GOB. (2005). Forest statistics (unpublished). Bangladesh Forest Department, Government of the Peoples' Republic of Bangladesh, Dhaka

Khan, NA. (1998). A Political Economy of Forest Resource Use: Case studies of social forestry in Bangladesh. Ashgate, Aldershot and Brookfield.

Khan, N. A., Choudhury, J. K., \& Huda, K. S. (2004). An overview of social forestry in Bangladesh. Forestry Sector Project, Government of Bangladesh, Dhaka.

MOEF/IUCN. (1990).The National Conservation Strategy of Bangladesh. Ministry of Environment and Forest, Government of Bangladesh and International Union for Conservation of Nature and Natural Resources, Dhaka.

Rahim, M.A., \& Islam, K. S. (1998). Multi storied tree/cropping system: a sustainable land use system and vertical yield achievements in a land scarce community forestry conditions. In: Proceedings of the international seminar on cultivating forests: alternative forest management practices and techniques for community forestry, Bangkok

Rahman, A. (1992). Participatory Approach to forest resource management in Bangladesh: some major initiatives and lessons learned. Paper prepared for International Seminar on Forest Administration and Management, Michigan. School of Natural Resources, Michigan.

Rashid, H. (1994). Review of the Forestry Sector. Project evaluation and identification team and agriculture sector team/CIDA. Ministry of Agriculture, Government of Bangladesh, Dhaka.

Roy, M. K. (2003). Forest, People and Environment. Paper presented in the Workshop on Importance of Non-formal Education Organized by Bangladesh POUSH.

Social Forestry Rules (SFR). (2002). Forest Department, Ministry of Environment and Forests. Government of the Peoples Republic of Bangladesh, Dhaka.

Social Forestry Rules (SFR). (2004). Forest Department, Ministry of Environment and Forests. Government of the Peoples Republic of Bangladesh, Dhaka.

Task Force. (1987). Participatory forestry in Bangladesh: Concepts, experiences and recommendations, a report to the Ministry of Agriculture, Dhaka.

Zaman, W. A. (1984). Public Participation in Development and Health Programs: Lessons from rural Bangladesh. University Press of America, USA. 